\title{
IP-10 as a Non Sputum Biomarker in TB Treatment Monitoring
}

\author{
Yuhpita Indah Efriyani, Ida Parwati, Nina Tristina, Anna Tjandrawati \\ Department of Clinical Pathology Faculty of Medicine Universitas Padjadjaran \\ Dr. Hasan Sadikin General Hospital Bandung, Indonesia
}

\begin{abstract}
There are currently still limitations in the diagnosis of tuberculosis (TB). Sputum collection as specimen for diagnosis is not only difficult but also has low sensitivity.In blood, IP-10/CXCL-10 chemokine plays a role in inducing the movements of chemotactic inflammatory cells towards the sites of inflammation. A high level of IP-10 is found in active pulmonary TB patients and significantly decline after the patients have completed the TB treatments. The aim of this study was to analyze the decline of the IP-10 level before and after 2 months of TB treatment. This study was conducted from March to Juni 2020. This was a comparative observational cohort study on active pulmonary TB patients who were $>18$ years old at the DOTS Clinic of Dr. Hasan Sadikin General Hospital Bandung. Thirty patients who met the inclusion criteria were followed up until 2 months of TB treatment. Serum of these patients were collected and examined for the IP-10 level before and after 2 months of TB treatment. It was demonstrated that the median IP-10 level in new active pulmonary TB patients was $384.1 \mathrm{pg} / \mathrm{mL}(136.70-$ $779.80)$ and dropped to $251.85 \mathrm{pg} / \mathrm{mL}(91.10-698.30)(\mathrm{p}<0.001)$ two months of TB treatment. Thus, the IP-10 level in the active pulmonary TB patients is significantly declined $(\mathrm{p}<0.001)$ after 2 months of TB treatment and that serum IP-10 level could be considered as a non-sputum-based marker to monitor TB treatment.
\end{abstract}

Keywords: IP-10, tuberculosis, tuberculosis treatment monitoring

\section{IP-10 sebagai Biomarker Non-Sputum pada Monitoring Pengobatan Tuberkulosis}

\begin{abstract}
Abstrak
Diagnosis tuberkulosis (TB) saat ini masih mengalami kendala. Pemeriksaan spesimen sputum selain pengambilannya sulit juga sensitivitasnya rendah, baik mikroskopik maupun kultur. Kemokin IP-10/CXCL-10 merupakan kemokin pro-inflamasi yang berperan menginduksi pergerakan sel inflamasi menuju lokasi inflamasi. Pada penderita TB paru aktif ditemukan kadar dalam serum tinggi dan menurun signifikan setelah penderita menyelesaikan pengobatan. Tujuan penelitian ini adalah menganalisis penurunan kadar IP-10 serum pada penderita TB paru aktif baru dibanding dengan 2 bulan pascapengobatan TB. Penelitian ini bersifat observasional komparatif dengan rancangan penelitian kohort. Subjek penelitian adalah penderita TB paru aktif baru berumur $>18$ tahun yang berobat ke Poliklinik DOTS Rumah Sakit Dr. Hasan Sadikin Bandung yang diikuti sampai 2 bulan pengobatan. Serum subjek sebelum dan setelah pengobatan 2 bulan dikumpulkan serta disimpan pada suhu $-80^{\circ} \mathrm{C}$ sampai pemeriksaan kadar IP-10. Penelitian ini dilakukan sejak Maret sampai Juni 2020. Terdapat 30 subjek yang memenuhi kriteria inklusi. Median kadar IP-10 pada penderita TB paru aktif baru adalah 384,1 $\mathrm{pg} / \mathrm{mL}(136,70-779,80)$, menurun bermakna setelah pengobatan 2 bulan, yaitu 251,85 pg/mL $(91,10-698,30)$ $(\mathrm{p}<0,001)$. Simpulan, penelitian ini menunjukkan kadar IP-10 dapat digunakan sebagai penanda berbasis nonsputum untuk monitoring pengobatan TB.
\end{abstract}

Kata kunci: IP-10, monitoring pengobatan tuberkulosis, tuberkulosis

Corresponding Author: Ida Parwati, Department of Clinical Pathology Faculty of Medicine Universitas Padjadjaran/Dr. Hasan Sadikin General Hospital, Bandung. Jalan Pasteur No 38 Bandung, West Java, Indonesia, Email: idaparwati2008@gmail. com/ida.parwati@unpad.ac.id, 


\section{Introduction}

Tuberculosis (TB) is one of the top 10 causes of death worldwide and Indonesia has the second highest incidence in the world, after India. ${ }^{1}$ Currently, there are still limitations in the diagnosis of TB. Specimen collection from sputum is not only difficult but also produce a low sensitivity in both microscopic and culture examination. In addition, Xpert MTB/RIF assay requires laboratory facilities and experts. ${ }^{2}$

Evaluation of $\mathrm{TB}$ treatment still relies on sputum conversion after the first 2 months of TB treatment, which actually cannot be fully used as an indicator of the success of treatment. ${ }^{3,4}$ Since 2015, World Health Organization (WHO) has been encouraging scientists towards the discovery of new non-sputum-based diagnostic methods from the individual host's responses, aiming to increase the sensitivity and specificity of pulmonary TB diagnosis as well as assisting in TB treatment evaluation. ${ }^{5}$ Currently, the host response is a concern for studies as available host response tests such as Interferon- $\gamma$ (IFN- $\gamma$ ) or known as the interferon gamma release assay (IGRA) cannot be used to differentiate between active TB and latent TB as well as for monitoring TB treatment result. .-8 $^{-8}$

There are other cytokines and chemokines that have been studied as alternative markers of host response to Mycobacterium tuberculosis (MTB) infection, such as $\mathrm{C}-\mathrm{X}-\mathrm{C}$ motif chemokine ligand 10 (CXCL10) or interferon- $\gamma$ inducible protein 10 (IP-10). The IP-10 is a pro-inflammatory chemokine which is stimulated by IFN- $\gamma$ in the site of inflammation as the response to MTB infection. This chemokine plays a role in inducing the movements of chemotactic inflammatory cells towards the sites of inflammation. ${ }^{9-11}$ IP-10 is produced mainly by the antigen presenting cell (APC) and the level is 100-fold higher than IFN- $\gamma$ after MTB infection., ${ }^{6,11}$ A high level of IP10 iss found in active pulmonary TB patients and decreases significantly after the completion of the anti-TB treatments. ${ }^{12}$ This study aimed to analyze the decrease of the IP-10 level before and after 2 months of TB treatment.

\section{Methods}

This was a comparative observational cohort study as a part of "Using host-responses and pathogen genomics to improve diagnostics for tuberculosis in Indonesia" research in collaboration with the London School of Hygiene and Tropical Medicine. Subjects were active pulmonary TB patients aged $>18$ years old who were treated at the DOTS clinic of Dr. Hasan Sadikin General Hospital Bandung, Indonesia. Subjects were diagnosed by clinicians based on the International Standard of Tuberculosis Care (ISTC) and followed for 2 months. ${ }^{13}$ Only subjects with total compliance were included in this study. The total compliance was defined as patients who perform visits and take medication according to the doctor's instructions, while noncompliance was defined as patients who stop taking TB treatment or not taking TB treatment properly. $^{14}$

The exclusion criteria in this study were patients with extrapulmonary TB, malignancy and/or undergoing chemotherapy, diabetes mellitus, hepatitis $\mathrm{B}$ and $\mathrm{C}$, human immunodeficiency virus (HIV), pulmonary infection other than TB, and having steroid or immunomodulatory therapy for more than 2 weeks. The exclusion criteria were based on patient's history, physical examination, chest X-ray and laboratory results ffasting blood glucose and 2 hours post prandial test, anti-HIV test, hepatitis B surface antigen test (HBsAg), and hepatitis $\mathrm{C}$ antibody test (anti-HCV)\}.This study was conducted from March to June 2020.

Patients were instructed to provide sputum samples on the day of first attendance before TB treatment initiation. Samples were then examined using smear, culture, and GeneXpert method to confirm TB diagnosis. ${ }^{13}$ Three $\mathrm{mL}$ of blood were collected at D0 and D60 using plain vacutainer tubes and transported to the Central Laboratory of the Clinical Pathology Department, Dr. Hasan Sadikin General Hospital Bandung, Indonesia, and were centrifuged at $3000 \mathrm{~g}$ for 15 minutes. Serum were then stored at $-80^{\circ} \mathrm{C}$ for a maximum of 3 months before the IP-10 testing was performed. The measurement of the IP-10 levels used was the sandwich enzyme-linked immunosorbent assay (ELISA) method..$^{15}$ Data were then analyzed for normality using the Saphiro-Wilk test and the difference was assessed using the Wilcoxon Signed Ranks Test using the Statistical Package for the Social Science (SPSS) software version 24.0 for Windows. This study applied 95\% confidence level $(\alpha=0.05)$ with a $p$ value of $<0.05$ deemed to be statistically significant difference. Ethical approval for this study was obtained from the Health Research Ethics Committee of Dr. Hasan Sadikin General Hospital Bandung, Indonesia, through the issuance of the ethical clearance No. LB.02.01/X.6.5/61/2020. 
Table 1 Subject Characteristics

\begin{tabular}{|c|c|c|}
\hline Variable & Value & $(n=30)$ \\
\hline \multicolumn{3}{|l|}{ Gender } \\
\hline Male & & 17 \\
\hline Female & & 13 \\
\hline Age (year)* & $37 \pm 12$ & \\
\hline \multicolumn{3}{|l|}{ GeneXpert examination } \\
\hline Sensitive & & 5 \\
\hline Resistant & & 25 \\
\hline \multicolumn{3}{|l|}{ Smear examination } \\
\hline Negative & & 11 \\
\hline Scanty & & 5 \\
\hline Positive 1 & & 9 \\
\hline Positive 2 & & 2 \\
\hline Positive 3 & & 3 \\
\hline \multicolumn{3}{|l|}{ Culture examination } \\
\hline Positive & & 26 \\
\hline Negative & & 4 \\
\hline \multicolumn{3}{|l|}{ Chest X-ray examination } \\
\hline Mild & & 4 \\
\hline Moderate & & 15 \\
\hline Severe & & 11 \\
\hline \multicolumn{3}{|l|}{ Laboratory examination } \\
\hline Leukocyte count $\left(/ \mathrm{mm}^{3}\right)^{*}$ & $8.396 \pm 2.216$ & \\
\hline Total neutrophils $\left(10^{3} / \mathrm{uL}\right)^{*}$ & $5.74 \pm 2.06$ & \\
\hline Total lymphocytes $\left(10^{3} / \mathrm{uL}\right)^{*}$ & $1.72 \pm 0.71$ & \\
\hline Total monocytes $\left(10^{3} / \mathrm{uL}\right)^{\wedge}$ & $0.6(0.22-1.42)$ & \\
\hline Total eosinophils $\left(10^{3} / \mathrm{uL}\right)^{\wedge}$ & $0.08(0.01-0.49)$ & \\
\hline
\end{tabular}

\section{Results}

Between March and June 2020, 30 subjects were enrolled with male subjects outnumbered the female subjects. The mean age of the subject were $37 \pm 12$ years old. During this study, most subjects suffered from MDR-TB. Nevertheless, the levels of IP-10 were not statistically difference between sensitive and MDR-TB subjects. A similar condition was also found in the positivity of smear examination. Leukocytes as the producer of IP-10 were found to be within normal limits. No analysis was performed to elaborate the relation between the type of leukocytes and the IP-10 level. The characteristics of subjects enrolled in the study are listed in Table 1.

The median IP-10 levels before and after two months of TB treatment demonstrated that the

Table 2 Differences of Serum IP-10 Levels in New Active Pulmonary TB Patients and After 2 Months of TB Treatment

\begin{tabular}{lccc}
\hline $\begin{array}{c}\text { Serum IP-10 level } \\
(\mathbf{p g} / \mathbf{m L})\end{array}$ & $\begin{array}{c}\text { Before Treatment } \\
(\mathbf{N}=\mathbf{3 0})\end{array}$ & $\begin{array}{c}\text { After 2 Months of TB Treatment } \\
(\mathbf{N}=\mathbf{3 0})\end{array}$ & P value \\
\hline Median & 384.1 & 251.85 & $<0.001$ \\
Range & $(136.70-779.80)$ & $(91.10-698.30)$ & \\
\hline
\end{tabular}


IP-10 level median decreased significantly from $384.1 \mathrm{pg} / \mathrm{mL}$ to $251.85 \mathrm{pg} / \mathrm{mL}(\mathrm{p}<0.001)$ after 2 months of TB treatment as presented in Table 2.

\section{Discussion}

Sputum smear and culture conversion at 2 months has long been used as the predictor of a successful TB treatment; however, sputum samples at 2 months of TB treatment are difficult to obtain in patients who respond to therapy. Subsequently, other biomarkers for monitoring TB treatment are needed.

IP-10 is a pro-inflammatory chemokine that is secreted by macrophages and dendritic cells in the lung organs as a response to MTB Infection. The IP-10 induces the Th1 cells to return to the lung organs and produce interferon gamma, TNF- $\alpha$, and IL-2. Interferon gamma (IFN- $\gamma$ ) is a more dominant cytokine that stimulates the APC to produce IP-10, when compared to TNF- $\alpha$ and IL-2, at the site of MTB infection. A high level of IP-10 is found after TB exposure or reactivation of a latent infection and then a decrease is observed after 2 months of TB treatment due to the reduced number of activated MTB and IFN- $\boldsymbol{\gamma}$ response to T cells. ${ }^{6,10,11}$ Those properties have made IP-10 a promising candidate for the surrogate biomarker for active TB infection and for monitoring the results of TB treatment. $6,16,17$

In this cohort study, all possible infections and inflammation that could increase the IP10 level and interfere the measurement result were excluded. Patient compliance was also an important factor that was considered in this study. Most of the subjects who met the inclusion and exclusion criteria to participate in this study suffered from MDR-TB. Nevertheless, no statistical difference in the level of IP-10 was seen between sensitive and MDR-TB subjects. For that reason, analysis for MDR-TB and sensitive TB subjects was not differentiated. This feature is similar to the statement of Garcia et al. stating that the IP-10 level between sensitive and MDR-TB subjects is not different. The said study discovered that the IP-10 level decreases since the first week of TB treatment, which reflects the decrease of patient's bacteriological load. An IP-10 reduction of $>300 \mathrm{pg} / \mathrm{mL}$ in the first seven days of TB treatment is strongly associated with confirmed versus unconfirmed TB; thus, accordingly, the absence of these changes is predictive of unconfirmed TB. ${ }^{4}$

The result of this study is in line with the results in Hoel et al..$^{18}$ that demonstrated an IP-
10 level before treatment of $1081 \mathrm{pg} / \mathrm{mL}$ (8862321) and then decreases after 2 months TB treatment ( $\mathrm{p}=0.012$ ) down to $203 \mathrm{pg} / \mathrm{mL}$ (129427) $(p=0.028)$ at the end of TB treatment.

Although this study did not seek to identify the cut-off for serum IP-10 level for the purpose of active pulmonary TB diagnosis, Hong et al. ${ }^{10}$ have suggested a cut off of $>119.5 \mathrm{pg} / \mathrm{mL}$. Among the subjects in this present study, 4 subjects were found to be negative in culture and smear microscopy tests, but positive in the Xpert MTB/RIF test. In this case, the IP-10 level can be considered as a sensitive non-sputumbased marker to diagnose active pulmonary TB patients.

This study has a limitation in terms of the lack of analysis of the correlation between decreased IP-10 level after 2 months of TB treatment and patient's clinical conditions, laboratory results, and radiological findings.

To conclude, The IP-10 level in active pulmonary TB patients decreases significantly $(\mathrm{p}<0.001)$ after 2 months of TB treatment both for sensitive and MDR-TB patients. Therefore, the IP-10 can be used as a non-sputum-based biomarker for TB treatment monitoring. Further studies are still needed to prove the correlation between the IP-10 level and patient's clinical conditions, laboratory results, and radiological findings, as well as to explore the possibility of using the IP-10 as a new non-sputum-based biomarker for TB diagnostics.

\section{Acknowledgement}

The field work for this study is funded by Sistem Informasi Penelitian dan Pengabdian Kepada Masyarakat (SIMLITABMAS) under the "Using Host-Responses and Pathogen Genomics to Improve Diagnostics for Tuberculosis in Indonesia" study.

\section{References}

1. WHO. Global tuberculosis report 2020. France: WHO; 2020.

2. Santos VS, Goletti D, Kontogianni K, Adams ER, Molina-Moya B, Dominguez J, et al. Acute phase proteins and IP-10 as triage tests for the diagnosis of tuberculosis: systematic review and meta-analysis. Clin Microbiol Infect. 2019;25(2):169-77.

3. Goletti D, Lee R, Wang J-Y, Walter N, Ottenhoff T. Update on tuberculosis biomarkers: From 
correlates of risk, to correlates of active disease and of cure from disease. Respirology. 2018;23(5):455-66.

4. García-Basteiro AL, Mambuque E, den Hertog A, Saavedra B, Cuamba I, Oliveras L, et al. IP10 kinetics in the first week of therapy are strongly associated with bacteriological confirmation of tuberculosis diagnosis in hivinfected patients. Sci Rep. 2017;7(1):14302.

5. Goletti D, Petruccioli E, Joosten SA, Ottenhoff THM. Tuberculosis biomarkers: from diagnosis to protection. Infect Dis Rep. 2016;8(2):6568.

6. Tonby K, Ruhwald M, Kvale D, Dyrhol-Riise A. IP-10 measured by Dry Plasma Spots as biomarker for therapy responses in Mycobacterium Tuberculosis infection. Sci Rep. 2015;5:9223.

7. Wergeland I, Pullar N, Assmus J, Ueland T, Tonby K, Feruglio S, et al. IP-10 differentiates between active and latent tuberculosis irrespective of HIV status and declines during therapy. J Infect. 2015;70(4):381-91.

8. Villar-Hernández R, Latorre I, De SouzaGalvão ML, Jiménez MA, Ruiz-Manzano J, Pilarte J, et al. Use of IP-10 detection in dried plasma spots for latent tuberculosis infection diagnosis in contacts via mail. Sci Rep. 2019;9(1):3943.

9. Novel N. Chegou, Jan Heyckendorf, Gerhard Walzl, Christoph Lange, Ruhwald M. Beyond the IFN-c horizon: biomarkers for immunodiagnosis of infection with Mycobacterium tuberculosis. Eur Respir J. 2013;43(5):1472-86.

10. Hong JY, Jung GS, Kim H, Kim YM, Lee HJ, Cho $\mathrm{S}-\mathrm{N}$, et al. Efficacy of inducible protein 10 as a biomarker for the diagnosis of tuberculosis. Int J Infect Dis. 2012;16(12):e855-9.
11. Ruhwald M, Aabye MG, Ravn P. IP10 release assays in the diagnosis of tuberculosis infection: current status and future directions. Expert Rev Mol Diagn. 2012;12(2):175-87.

12. Kim SY, Kim J, Kim DR, Kang YA, Bong S, Lee J, et al. Urine IP-10 as a biomarker of therapeutic response in patients with active pulmonary tuberculosis. BMC Infect Dis. 2018;18(1):240.

13. USAID. International Standards for Tuberculosis Care TB care I. $3^{\text {rd }}$ ed. San Fransisco: United States Agency for International Development (USAID); 2014.

14. World Health Organization. MDR-TB Indonesia Update 2016. Indonesia: WHO; 2019. p. 1-2.

15. Elabscience. Human IP-10/ CXCL10(Interferon Gamma Induced Protein $10 \mathrm{kDa}$ ) ELISA Kit. Elabscience Biotechnology Inc. $7^{\text {th }}$ ed. Texas: Elabscience; 2017; . Available from: https://www.elabscience. com/p-human_ip_10_cxcl10_interferon_ gamma_induced_protein_10kda_elisa_kit17914.htmL.

16. El-emiry FA, Attia GA, Ahmad AY, Sakr BM. Diagnostic value of inducible protein-10 in pulmonary tuberculosis. Egyptian J Chest Dis Tuberculosis. 2016;65(1):219-25.

17. Mihret A, Bekele Y, Bobosha K, Kidd M, Aseffa A, Howe R, et al. Plasma cytokines and chemokines differentiate between active disease and non-active tuberculosis infection. J Infect. 2013;66(4):357-65.

18. Hoel IM, Jørstad MD, Marijani M, Ruhwald M, Mustafa T, Dyrhol-Riise AM. IP-10 dried blood spots assay monitoring treatment efficacy in extrapulmonary tuberculosis in a lowresource setting. Sci Rep. 2019;9(1):3871. 